\title{
Status gizi pada pasien penyakit ginjal kronik stadium 5 yang menjalani hemodialisis adekuat dan tidak adekuat
}

\author{
${ }^{1}$ Karsa S. Lajuck \\ ${ }^{2}$ Emma S. Moeis \\ ${ }^{2}$ Maarthen C. P. Wongkar
}

\author{
${ }^{1}$ Kandidat Skripsi Fakultas Kedokteran Universitas Sam Ratulangi Manado \\ ${ }^{2}$ Bagian Ilmu Penyakit Dalam Fakultas Kedokteran Universitas Sam Ratulangi Manado \\ Email: karsasambolangi_layuck@yahoo.com
}

\begin{abstract}
In stage 5 of chronic kidney disease, there is a progressive and irreversible damage in the kidney, therefore, the body is unable to maintain the normal metabolism as well as the fluid and electrolyte balance resulting in the increase of ureum. The management of patients in this stage is hemodialysis, a kind of kidney replacement therapies. Adequacy of hemodialysis is the determining indicator of dose sufficiency inpatients undergoing hemodialysis. Patients undergoing hemodialysis are under the risk of protein and energy malnutrition caused by the lack of food intake. This condition can be detected by using body mass index (BMI), protein, and albumin. This study was aimed to obtain the difference of nutritional status by measuring the BMI, protein, and albumin level in stage 5 CKD patients based on $\mathrm{Kt} / \mathrm{v}$, one of the parameter of dialysis adequacy. The study used a cross sectional design with 32 respondents who fulfilled the inclusion criteria. Data of dialysis adequacy based on $\mathrm{Kt} / \mathrm{v}$ and nutritional status using BMI, protein, and albumin levels were collected. The results showed that there were 20 respondents with adequate hemodialysis and 12 respondents with inadequate hemodialysis. Respondents aged 20-39 years had more adequate dialysis compared to those aged 40-60 years. The paired sample T-test showed that there was no significant difference between hemodialysis adequacy and BMI $(\mathrm{p}=0.414)$. However, there was a significant difference between hemodialysis adequacy and protein $(\mathrm{p}=0.043)$ as well as between hemodialysis adequacy and serum albumin $(\mathrm{p}=0.032)$. Conclusion: Nutritional status (protein and albumin) is a risk factor in stage 5 CKD patients with inadequate and adequate hemodialysis.
\end{abstract}

Keywords: patients with stage 5 chronic kidney disease on hemodialysis, nutritional status, adequacy of hemodialysis

\footnotetext{
Abstrak: Pada penyakit ginjal kronik (PGK) stadium 5, ginjal mengalami kerusakan yang progresif dan tidak dapat pulih kembali, tubuh tidak mampu memelihara metabolisme dan gagal memelihara keseimbangan cairan dan elektrolit berakibat peningkatan kadar serum ureum. Penatalaksanaan pasien PGK pada stadium ini yaitu hemodialisis sebagai salah satu tindakan terapi pengganti ginjal (TPG). Adekuasi hemodialisis merupakan indikator penentuan kecukupan dosis hemodialisis. Tindakan hemodialisis berisiko mengalami malnutrisi energi-protein akibat asupan makan yang kurang, juga disebabkan hilangnya protein serum saat tindakan hemodialisis yang dapat dideteksi dengan pengukuran indeks massa tubuh (IMT), protein, dan albumin. Penelitian ini bertujuan untuk mengetahui perbedaan status gizi dengan mengukur IMT, protein, dan albumin pada pasien PGK 5-HD berdasarkan Kt/V, sebagai salah satu parameter adekuasi dialisis. Desain penelitian potong lintang dengan 32 responden yang memenuhi kriteria inklusi. Dilakukan pengumpulan data mengenai adekuasi hemodialisis berdasarkan $\mathrm{Kt} / \mathrm{V}$, status gizi menggunakan IMT, protein, dan albumin. Dari hasil penelitian didapatkan 20 responden dengan hemodialisis yang adekuat dan 12 responden dengan hemodialisis yang tidak adekuat, dan kelompok usia 20-39 tahun memiliki hemodialisis yang adekuat dibanding kelompok usia 40-60 tahun. Uji paired sample T-Test mendapatkan tidak ada perbedaan bermakna antara adekuasi hemodialisis dan IMT $(\mathrm{p}=0,414)$ tetapi terdapat perbedaan bermakna antara adekuasi
} 
hemodialisis dan kadar protein $(\mathrm{p}=0,043)$ serta antara adekuasi hemodialisis dan albumin serum $(\mathrm{p}=0,032)$. Simpulan: Status gizi (albumin dan protein) merupakan faktor risiko pada pasien PGK 5-HD adekuat dan tidak adekuat.

Kata kunci: PGK stadium 5 hemodialisis, status gizi, adekuasi hemodialisis

Penyakit ginjal kronik (PGK) adalah kerusakan ginjal yang terjadi lebih dari 3 bulan, berupa kelainan struktural atau fungsional dengan atau tanpa penurunan laju filtrasi glomerulus dengan manifestasi kelainan patologik, terdapat tanda kelainan ginjal termasuk kelainan dalam komposisi darah atau urin atau dalam uji pencitraan (imaging test), dan laju filtrasi glomerulus (LFG) $<60 \mathrm{ml} / \mathrm{menit} / 1.73 \mathrm{~m}^{2}$ selama lebih 3 bulan dengan atau tanpa kerusakan ginjal. ${ }^{1}$

Prevalensi PGK saat ini terus mengalami peningkatan di seluruh negara di dunia. Diperkirakan lebih dari 50 juta penduduk dunia mengalami PGK dan 1 juta dari mereka membutuhkan terapi pengganti ginjal (TPG). Data tahun 2010 menunjukkan 59\% kematian di Indonesia disebabkan penyakit tidak menular, yang membutuhkan biaya pengobatan yang sangat besar yaitu salah satunya PGK. Indonesia termasuk salah satu negara dengan prevalensi angka kejadian PGK yang cukup tinggi, yaitu mencapai angka $20 \%$. $^{2}$

Pada PGK stadium 5, terjadi kerusakan ginjal yang progresif dan tidak dapat pulih kembali sehingga tubuh tidak mampu memelihara metabolisme dan gagal memelihara keseimbangan cairan dan elektrolit berakibat peningkatan ureum. Penatalaksanaan pasien PGK pada stadium ini dilakukan dengan tindakan TPG yaitu transplantasi ginjal, hemodialisis, peritoneal dialisis, dan konservatif. ${ }^{3}$

Hemodialisis (HD) merupakan salah satu TPG yang bertujuan untuk mengeluarkan sisa metabolisme protein atau mengoreksi gangguan keseimbangan air dan elektrolit, antara darah pasien dengan dialisat melalui membran semipermeabel yang bertindak sebagai ginjal buatan (dialyzer). Proses ini cukup efektif untuk menjaga homeostatis tubuh pasien. Faktor yang memengaruhi asupan makan disebabkan adanya gangguan gastrointestinal yaitu anoreksia dan mual sedangkan akibat tindakan HD dapat berupa hilangnya protein saat dilakukan dialisis. $^{4}$

Pasien PGK dengan HD mengalami risiko tinggi dari gangguan nutrisi. Masalah pada PGK stadium 5 yang menjalani hemodialisis (PGK 5-HD) ialah tingginya angka malnutrisi. ${ }^{5}$ Pasien PGK 5-HD harus mendapat asupan makanan yang cukup agar tetap dalam status gizi yang baik. Gizi yang kurang merupakan prediktor yang penting untuk terjadinya kematian pada pasien PGK 5-HD. Asupan protein diberikan $1,2 \mathrm{gr} / \mathrm{KgBB} /$ hari dengan $50 \%$ terdiri atas protein dengan nilai biologis yang tinggi. ${ }^{6}$

Kecukupan dari hemodialisis yang diberikan, diukur dengan adekuasi dialisis. Terdapat korelasi yang kuat antara adekuasi dialisis dengan angka morbiditas dan motilitas pada pasien PGK 5-HD. Adekuasi dialisis diukur dengan menghitung Urea Reduction Rate (URR) atau Kt/V. URR dihitung dengan mencari ratio hasil pengurangan kadar serum ureum predialisis dengan kadar serum ureum pasca dialisis dibagi kadar serum ureum predialisis. Pada hemodialisis 2 kali penghitungan, dialisis diaggap cukup bila URR $\geq 65 \%$. Penghitungannya menggunakan URR = ((Ur Pre-HD - Ur Pasca HD) : Ur Pre-HD $\mathrm{x} 100 \%$ ). Adekuasi hemodialisis juga diukur secara kuantitatif dengan menghitung $\mathrm{Kt} / \mathrm{V}$ yang merupakan rasio dari bersihan urea dan waktu hemodialisis dengan volume distribusi urea dalam cairan tubuh pasien. Pasien yang menjalani hemodialisis $2 \mathrm{kali} /$ minggu diberi target $\mathrm{Kt} / \mathrm{V}$ 1,8. Cara lain menghitung adekuasi dengan menghitung $\mathrm{Kt} / \mathrm{V}$ dengan rumus Daugirdas. $^{1}$

Penelitian ini dilakukan untuk 
mengetahui perbedaan status gizi dengan mengukur parameter IMT, protein dan albumin pada pasien PGK 5-HD berdasarkan adekuat dan tidak adekuat hemodialisis, dan $\mathrm{Kt} / \mathrm{V}$ sebagai parameter untuk adekuasi dialisis.

\section{METODE PENELITIAN}

Jenis penelitian yang digunakan ialah analitik observasional dengan desain potong lintang. Penelitian dilakukan sejak bulan Oktober hingga November 2016 di Unit Hemodialisis RSUP Prof. Dr. R.D Kandou Manado.

Subyek penelitian ialah pasien PGK 5 HD yang memenuhi kriteria inklusi dan ekslusi. Kriteria inklusi yaitu usia 20-60 tahun, laki-laki atau perempuan, menjalani hemodialisis reguler, dan lama menjalani $\mathrm{HD} \geq 3$ tahun. Kriteria eksklusi yaitu pasien PGK dengan data rekam medik yang tidak lengkap.

Variabel bebas ialah subyek penelitian yang menjalani HD adekuat dan tidak adekuat sedangkan variabel tergantung ialah parameter status gizi yaitu IMT, protein, dan albumin.

Hemodialisis yang adekuat dan tidak adekuat diukur berdasarkan adekuasi hemodialisis dengan menggunakan rumus logaritma natural $\mathrm{Kt} / \mathrm{V}$ yang merupakan rasio dari bersihan urea (ureum pre dan post HD) dan waktu hemodialisis dengan volume distribusi urea dalam cairan tubuh pasien. Data adekuasi hemodialisis subyek penelitian didapatkan dari data pada alat HD.

Untuk pengukuran Indeks Massa Tubuh (IMT) diperoleh dengan penghitungan berat badan $(\mathrm{kg})$ dibagi dengan tinggi badan (m) kuadrat kemudian dituliskan hasilnya dalam bentuk angka. Protein dan albumin diperoleh melalui data pemeriksaan laboratorium dalam rekam medik.

\section{HASIL PENELITIAN}

Pada peneltian ini jumlah subyek penelitian yang memenuhi kriteria inklusi ialah 32 orang yang diambil dari data primer di Unit Hemodialisis RSUP Prof.
Dr. R. D. Kandou Manado. Sebagian besar subyek penelitian menjalani hemodialisis adekuat $(62,5 \%)$ dan sebanyak $37,5 \%$ menjalani hemodiaisis yang tidak adekuat.

Pada penelitian ini juga dideskripsikan atas 4 kelompok yaitu kelompok usia 20-29 tahun, 30-39 tahun masing-masing 6 orang, serta kelompok usia 40-49 tahun dan 50-60 tahun masing-masing 4 orang untuk pasien dengan HD adekuat dan tidak adekuat.

Tabel 1 menunjukkan dari 32 subyek penelitian sebanyak 17 orang $(53,1 \%)$ memiliki IMT normal dan 15 orang $(46,9 \%)$ orang memiliki IMT abnormal. Dalam uji analisis dengan risiko relatif, $\mathrm{RR}=1,43$ yang artinya IMT sebagai faktor risiko dalam adekuasi hemodialisis. Berdasarkan risiko odds $(\mathrm{RO}=2,11)$ maka pada pasien HD tidak adekuat sebesar 2.11 kali mengalami IMT abnormal dibanding pada proses HD adekuat. Analisis uji paired sample t-test menunjukkan bahwa adekuasi hemodialisis dan IMT tidak memiliki perbedaan bermakna secara statistik $(\mathrm{P}=0,414)$.

Tabel 1. IMT berdasarkan adekuasi hemodialisis

\begin{tabular}{lccc}
\hline \multirow{2}{*}{$\begin{array}{c}\text { Adekuasi HD } \\
(\mathbf{K T} / \mathbf{V})\end{array}$} & \multicolumn{3}{c}{ IMT } \\
\cline { 2 - 4 } & Normal & Abnormal & Total \\
\hline Adekuat $>1,8$ & 12 & 8 & 20 \\
Tidak adekuat & 5 & 7 & 12 \\
$<1,8$ & 17 & 15 & 32 \\
Total & 17 \\
\hline Uji $t$-test, $R R=1.43, R O=2.11, P=0.414$
\end{tabular}

Tabel 2 menunjukkan dari 32 subyek penelitian, sebanyak 25 orang memiliki protein normal dan 7 orang orang memiliki protein abnormal. Dalam uji analisis dengan risiko relatif, $R R=1.2$ yang artinya protein sebagai faktor risiko dalam adekuasi hemodialisis. Berdasarkan risiko odds $(\mathrm{RO}=2,35)$ maka pada pasien HD tidak adekuat sebesar 2,35 kali mengalami protein abnormal dibanding pada proses HD adekuat. Analisis uji paired sample t-test menunjukkan bahwa adekuasi hemodialisis dan protein memiliki perbedaan bermakna secara statistik $(\mathrm{P}=0,043)$. 
Tabel 2. Protein berdasarkan adekuasi hemodialisis

\begin{tabular}{lccc}
\hline $\begin{array}{l}\text { Adekuasi HD } \\
(\text { KT } / \text { V })\end{array}$ & \multicolumn{3}{c}{ Protein } \\
\cline { 2 - 4 } & Normal & Abnormal & Total \\
\hline $\begin{array}{l}\text { Adekuat }>1,8 \\
\text { Tidak adekuat }\end{array}$ & 16 & 3 & 19 \\
$<1,8$ & 9 & 4 & 13 \\
Total & 25 & 7 & 32 \\
\hline Uji -test $, R R=1.2, R O=2.35, P=0.043$
\end{tabular}

Tabel 3 menunjukkan dari 32 subyek penelitian, sebanyak 28 orang dengan albumin normal dan 4 orang dengan albumin abnormal. Dalam uji analisis dengan risiko relatif, $\mathrm{RR}=1,1$ yang artinya albumin sebagai faktor risiko dalam adekuasi hemodialisis. Berdasarkan risiko odds $(\mathrm{RO}=2,11)$ maka pada pasien $\mathrm{HD}$ tidak adekuat sebesar 2,11 kali mengalami albumin abnormal dibanding pada proses HD adekuat. Analisis uji paired sample ttest menunjukkan bahwa adekuasi hemodialisis dan albumin memiliki perbedaan secara statistik $(\mathrm{P}=0,032)$.

Tabel 3. Albumin berdasarkan adekuasi hemodialisis

\begin{tabular}{lccc}
\hline \multirow{2}{*}{$\begin{array}{l}\text { Adekuasi HD } \\
(\text { KT/V) }\end{array}$} & \multicolumn{3}{c}{ Albumin } \\
\cline { 2 - 4 } & Normal & Abnormal & Total \\
\hline $\begin{array}{l}\text { Adekuat }>1,8 \\
\text { Tidak adekuat }\end{array}$ & 19 & 2 & 21 \\
$<1,8$ & 9 & 2 & 11 \\
Total & 28 & 4 & 32 \\
\hline \multicolumn{1}{l}{ Uji t-test $R R=1.1, R O=2.11, P=0.032$} \\
\hline
\end{tabular}

\section{BAHASAN}

Pencapaian adekuasi hemodialisis diperlukan untuk menilai efektivitas tindakan hemodialisis yang dilakukan. ${ }^{7}$ Hemodialisis yang adekuat akan memberikan manfaat yang besar dan memungkinkan pasien gagal ginjal tetap bisa menjalani aktivitasnya seperti biasa Terdapat hubungan yang kuat antara adekuasi hemodialisis dengan morbiditas dan mortalitas pasien gagal ginjal. ${ }^{8}$

Pourfarziani et al. ${ }^{9}$ meneliti adekuasi 338 pasien hemodialisis di Iran dan mendapatkan bahwa bersihan urea yang tidak optimal pada hemodialisis yang tidak adekuat akan meningkatkan morbiditas dan mortalitas pasien hemodialisis. Hemodialisis yang tidak adekuat juga mengakibatkan kerugian material dan menurunnya produktivitas pasien hemodialisis. Proses hemodialisis yang adekuat sebaliknya akan memberikan dampak yang positif terhadap peningkatan kualitas hidup pasien hemodialisis. ${ }^{8}$

Usia merupakan salah satu faktor yang dapat mempengaruhi status kesehatan individu. Proses degeneratif yang terjadi setelah usia 40 tahun akan mengakibatkan terjadinya perubahan anatomi, fisiologi, dan biokimia sehingga menyebabkan penurunan kerja ginjal dan kualitas hidup $1 \%$ setiap tahunnya. ${ }^{10}$ Pada usia 40-70 tahun, laju filtrasi glomerulus akan menurun secara progresif hingga 50\% dari normal, terjadi penurunan kemampuan tubulus ginjal untuk mereabsorbsi dan pemekatan urin, penurunan kemampuan pengosongan kandung kemih dengan sempurna sehingga meningkatkan resiko infeksi dan obstruksi, dan penurunan intake cairan yang merupakan faktor risiko terjadinya kerusakan ginjal. ${ }^{10}$

Status gizi pada subyek penelitian yaitu berdasarkan IMT, protein, dan albumin. Berdasarkan hasil penelitian pada pasien hemodialisis didapatkan sebagian besar memiliki IMT normal. Hal ini sesuai dengan penelitian yang dilakukan Junaidi ${ }^{11}$ dan Sulistyowati ${ }^{12}$ yang mendapatkan sebagian besar pasien HD dikategorikan status gizi normal.

Pasien hemodialisis rentan mengalami malnutrisi. Malnutrisi akan meningkatkan angka morbiditas dan mortalitas. ${ }^{12}$

Dalam uji statistik IMT tidak memiliki perbedaan yang bermakna $(\mathrm{P}=0.414)$. Uji analisis dengan risiko relatif $\mathrm{RR}=1.43$ yang artinya IMT sebagai faktor risiko dalam adekuasi hemodialisis. Berdasarkan risiko odds $(\mathrm{RO}=2,11)$ maka pada pasien HD tidak adekuat sebesar 2,11 kali mengalami IMT abnormal dibanding pada proses HD adekuat. Hasil ini sesuai dengan penelitian yang dilakukan oleh Dewantari et al. ${ }^{13} \mathrm{Hal}$ tersebut dikaitkan dengan sindroma uremia 
yang menyebabkan anoreksia, mual, muntah pada pasien yang menjalani hemodialisis tidak adekuat. Selain itu, faktor lain yang ikut berpengaruh ialah luas permukaan tubuh. Pasien yang memiliki IMT rendah cenderung memiliki luas permukaan tubuh yang lebih kecil dibandingkan dengan pasien yang memiliki IMT tinggi. Hal ini menyebabkan bersihan ureum dengan waktu yang sama akan lebih optimal terjadi pada pasien dengan luas permukaan tubuh yang lebih kecil. ${ }^{13}$

Hasil penelitian protein dan albumin sebagai indikator status gizi, protein $(\mathrm{p}=0,043)$ dan albumin $(0,032)$ memiliki perbedaan bermakna secara statistik. Uji analisis protein dengan risiko relatif, $\mathrm{RR}=1,2$ yang artinya protein sebagai faktor risiko dalam adekuasi hemodialisis. Berdasarkan risiko odds $(\mathrm{RO}=2,35)$ maka pada pasien HD tidak adekuat sebesar 2,35 kali mengalami protein abnormal dibanding pada proses HD adekuat. Uji analisis albumin dengan risiko relatif $R R=1.1$ yang artinya albumin sebagai faktor risiko dalam adekuasi hemodialisis. Berdasarkan risiko odds $(\mathrm{RO}=2,11)$ maka pada pasien HD tidak adekuat sebesar 2,11 kali mengalami albumin abnormal dibanding pada proses HD adekuat. Terapi hemodialisis sendiri dapat pula menyebabkan keadaan hipoalbuminemia yang dapat memperburuk kelangsungan hidup pasien hemodialisis. ${ }^{14}$ Kadar albumin <3,5 gram/dl termasuk faktor risiko utama mortalitas pada pasien hemodialisis. Kadar albumin plasma berhubungan dengan simpanan protein tubuh. ${ }^{14}$ Penelitian yang dilakukan oleh Pupim et al. ${ }^{15}$ menyatakan bahwa pasien HD dengan kondisi malnutrisi ditunjukkan oleh rendahnya albumin. Rekomendasi jumlah asupan protein pasien HD sebesar $1,2 \mathrm{~g} / \mathrm{kg} \mathrm{BB} / \mathrm{hr}$ diharapkan dapat terjadi keseimbangan nitrogen netral atau positif dan dapat meningkatkan kadar albumin. ${ }^{15}$ Kaysen et al. ${ }^{16}$ melaporkan bahwa inflamasi dan asupan zat gizi yang tidak adekuat dapat menurunkan konsentrasi serum albumin. Penelitian oleh Belizi et al. ${ }^{17}$ dan Williams et al. ${ }^{18}$ menyatakan terdapat hubungan antara asupan protein dengan kadar albumin pasien HD. Dalam kaitan adekuasi hemodialisis dengan protein dan albumin, hal ini mungkin dipengaruhi oleh kecukupan protein yang bukan berasal dari protein dengan nilai biologis yang tinggi seperti yang direkomendasikan oleh NKF-K/DOQI. ${ }^{19}$ Asupan protein yang dianjurkan ialah asupan protein dengan nilai biologis tinggi (protein hewani). ${ }^{19}$

\section{SIMPULAN}

Berdasarkan hasil penelitian pada pasien dengan hemodialisis adekuat dan tidak adekuat dapat disimpulkan bahwa sebagian besar subyek penelitian menjalani hemodialisis adekuat terutama pada kelompok usia 20-39 tahun. Pada pasien dengan hemodialisis adekuat dan tidak adekuat tidak terdapat perbedaan bermakna terhadap IMT tetapi terdapat perbedaan bermakna terhadap protein dan albumin. Status gizi berdasarkan protein dan albumin sebagai faktor risiko terhadap adekuasi hemodialisis.

\section{SARAN}

Perlunya edukasi mengenai pentingnya asupan makan pada pasien yang menjalani hemodialisis dan pentingnya menhitung adekuasi dialisis yang dilakukan saat pasien penyakit ginjal kronik stadium 5 menjalani hemodialisis reguler.

\section{DAFTAR PUSTAKA}

1. Suwitra K. Penyakit Ginjal Kronik. Buku Ajar Ilmu Penyakit Dalam (6th ed). Jakarta: Interna Publishing, 2014; p. 2159-65.

2. Adiatma DC. Prevalensi dan jenis anemia pada pasien penyakit ginjal kronik yang menjalani hemodialisis reguler. [cited 2016 sep 10]. Available from: ejournal.undip.ac.id.

3. Angraini DI. The different of protein intake between chronic renal failure patients with malnutrition and not malnutrition in Hemodialysis Unit at dr. Abdul Moeloek Hospital Bandar Lampung. Jurnal Kedokteran dan Kesehatan. 2015; 2:163-168.

4. Adriani M, Zuyana L. Perbedaan asupan 
makan dan status gizi antara pasien hemodialisis adekuat dan inadekuat penyakit ginjal kronik. Media Gizi Indonesia. 2013;9(1):13-9.

5. Ikizler AT. A patient with CKD and poor nutritional status. Clin J Am Socneprhol. 2013;8(12):2174-82.

6. KDIGO. Clinical Practice Guideline for the evaluation and management of chronic kidney disease. Journal of the International Society of Nephrology. 2012;2:3.

7. Septiwi C. Hubungan antara adekuasi hemodialisis dengan kualitas hidup pasien hemodialisis di Unit Hemodialisis RS. Prof. Dr. Margono Soekarjo Purwekerto [Tesis]. Jakarta: Fakultas Ilmu Keperawatan Medikal Bedah Universitas Indonesia; 2010.

8. Pourfarziani V, Ghanbarpour F, Nemati E, Taheri S, Einollahi B. Laboratory variables and treatment adequacy in hemodialysis patients in Iran. Saudi Journal of Kidney Disease and Transplantation. 2008;19(5):842-846.

9. Prabawati A. Faktor-faktor yang berhubungan dengan kualitas hidup pasien hemodialisis di RSU Dr. Sutomo Surabaya. [Online]; 2008 [cited 2016 Nov 15]. Available from: http://adln.lib.unair.ac.id/go.php.

10. Santoso. Gagal ginjal kronik. [Online]; 2010 [cited 2016 Nov 15]. Available from: http://www.antiloans.org.

11. Junaidi MA. Status indeks massa tubuh pasien penyakit ginjal kronik yang menjalani hemodialisis di Rumah Sakit Cipto Mangunkusumo dan korelasinya dengan lama menjalani hemodialisis [Skripsi]. Jakarta; FKUI; 2009.

12. Sulistyowati, N. Hubungan adekuasi hemodialisis dengan asupan makanan dan status gizi pasien gagal ginjal kronik yang menjalani hemodialisis di RSUP Dr. Kariadi Semarang [Tesis].

[Online]; 2009 [cited 2016 Nov 15]. Available from: eprints.undip.ac.id.

13. Dewantari EO, Taruna A, Angraini DI, Dilangga P. Hubungan adekuasi hemodialisis dengan asupan makan dan indeks massa tubuh pasien gagal ginjal kronik yang menjalani hemodialisis di RSUD. Abdul Moeloek Bandar Lampung. [Online]; 2014 [cited 2016 Nov 15]. Available from:.juke.kedokteran.unila.ac.id/inde x.php/majority/article/download/173/ 171.

14. Sja'bani, M. Arti klinis pemeriksaan albumin serum sebagai petanda progres malnutrisi dengan metode BCG dan elektroforesis pada penderita hemodialisis rutin. Berkala Ilmu Kedokteran. 1998;30(4).

15. Pupim LB, Flakoll PJ, Ikizler TA. Exercise Improves Albumin Fractional Synthetic Rate in Chronic Hemodialysis Patients. European Journal of Clinical Nutrition. 2007.

16. Kaysen, GA, Velden MG. New insights into lipid metabolism in the nephrotic syndrome. Kidney International. 1999; 55:18-21.

17. Belizi V, Scalfi L, Terracciano V, de Nicola L, Minutolo R, Marra M, et al. Early changes in bioelectrical estimates of body composition in CKD. J Am Soc Nephr. 2006; 17:1481-1487.

18. Williams AW, Chebrolu SB, Ing TS. Early clinical, quality of life, and biochemical changes of daily hemodialysis. American Journal of Kidneys Diseases. 2004; 43(1).

19. Marckmann P, Frandsen E, Ekelund B, Hvidtfeld D, et al. Nutritional status of maintenance dialysis patients: Low lean body mass index and obesity are common, protein-energy wasting is uncommon. [Online]; 2016 [cited 2016 Nov 15]. Available from: DOI:10.1371/journal.pone.0150012 